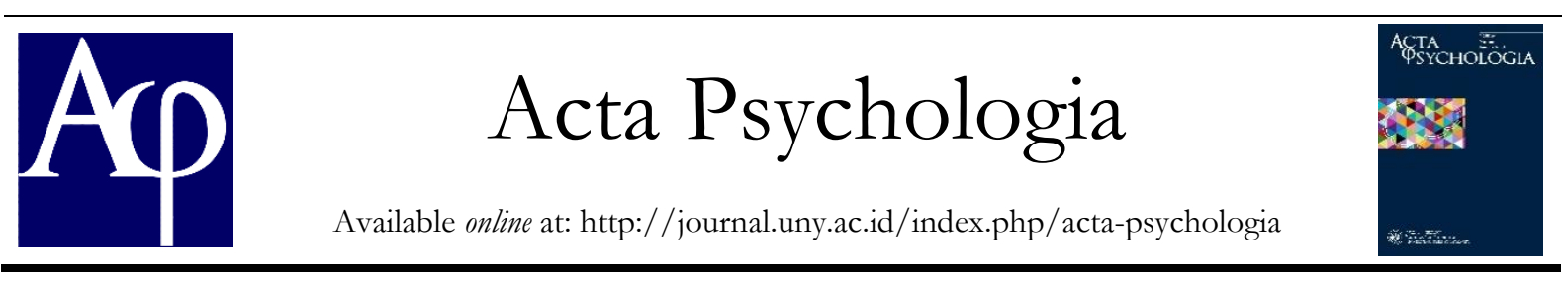

\title{
Hubungan Antara Intensitas Penggunaan Media Sosial dan Tingkat Depresi pada Mahasiswa
}

\author{
Asma Abidah Al Aziz \\ Program Studi Psikologi, Fakultas Ilmu Pendidikan, Universitas Negeri Yogyakarta; Jl. Colombo No. \\ 1 Sleman Yogyakarta, 55281 \\ asmaabidah27@gmail.com
}

\begin{abstract}
Abstrak
Tujuan penelitian ini adalah; 1) mengetahui tingkat depresi dan intensitas penggunaan media sosial pada mahasiswa, 2) hubungan intensitas penggunaan media sosial dan tingkat depresi pada mahasiswa. Penelitian ini menggunakan penelitian korelasional, jenis ex post facto. Subjek penelitian sebanyak 250 mahasiswa Fakultas Ilmu Pendidikan Universitas Negeri Yogyakarta yang ditentukan melalui teknik accidental sampling. Teknik pengumpulan data yang digunakan berupa angket yang terdiri dari instrumen pengukuran intensitas penggunaan media sosial dan Beck Depression Inventory (BDI-II). Hasil penelitian menunjukkan bahwa mahasiswa memiliki tingkat depresi dan intensitas penggunaan media sosial dalam kategori sedang. Koefisien korelasi yang diperoleh 0,147 dengan probabilitas $0,02(\mathrm{p}<0,05)$ dan koefisien determinasi sebesar $\left(\mathrm{R}^{2}\right) 2,2 \%$. Hasil penelitian tersebut menunjukkan bahwa terdapat hubungan positif antara intensitas penggunaan media sosial dan tingkat depresi. Semakin tinggi intensitas penggunaan maka semakin tinggi tingkat depresi pada mahasiswa.
\end{abstract}

Kata Kunci: intensitas, media sosial, depresi, mahasiswa

\begin{abstract}
The purposes of this study are to: (1) Determine the level of depression and the intensity of social media use on college students, (2) The corellations between the intensity of social media use and the level of depression in college students. The research subjects were 250 college students of the Faculty of Education of Yogyakarta State University using accidental sampling. This study used a quantitative approach with a type of correlational research, collected using an intensity of social media uses scale and Beck Depression Inventory (BDI-II). The results showed that collage students had a moderate level of depression and intensity of social media use. The correlation coefficient obtained 0.147 with a probability of $0.02(\mathrm{p}<0,05)$ and a coefficient of determination of (R2) $2.2 \%$. The results of the study indicate that there is a positive relationship between the intensity of social media use and the level of depression. This means that the higher intensity of social media uses will be build the higher level of depression in the college students..
\end{abstract}

Keywords: intensity, social media, depression, college students

\section{Pendahuluan}

Banyak peneliti sepakat bahwa penggunaan media sosial berhubungan dengan depresi. Salah satu penelitian yang dilakukan oleh Shensa, Escobar-Viera, Sidani, Bowman, Marshal, dan Primack (2017:1) menemukan adanya kaitan erat antara masalah dalam penggunaan media sosial dengan simptom-simptom depresi. Permasalahan penggunaan media sosial yang dimaksud, diantaranya adalah cyberbullying, perasaan khawatir yang timbul akibat kecanduan menggunakannya, dan adanya kecemburuan terhadap kehidupan orang lain yang terlihat berbeda di media 
sosial (Rosenthal, Buka, Marshall, Carey, \& Clark 2016:2). Eksperimen dari University of Pittsburgh membuktikan bahwa orang yang terlampau aktif menggunakan media sosial memiliki risiko depresi hingga tiga kali lebih besar dibandingkan mereka yang jarang memakai media sosial (Wisnubrata, 2018:1). Penggunaan media sosial dapat dikatakan aktif jika lebih dari 3 jam dalam sehari (Juditha, 2011:14).

Mahasiswa termasuk salah satu kelompok pengguna aktif media sosial sekaligus usia terbanyak pengguna media sosial. Berdasarkan hasil survey pengguna media sosial mencapai persentase 89,7\%, pada kelompok mahasiswa yang mayoritas berusia 18-25 tahun memiliki jumlah terbanyak dibandingkan dengan kelompok lainnya (Handikasari, Jusup, \& Johan, 2018: 920). Hasil survei dari Global Web Index tahun 2019 menyatakan bahwa rata-rata durasi penggunaan media sosial pada kelompok usia mahasiswa selama 3.26 jam perhari (Kemp, 2019:1). Jumlah intensitas tersebut dikhawatirkan dapat memberikan dampak negatif bagi mahasiswa, salah satunya depresi. Penelitiaan University of Pennsylvania menemukan bahwa tingginya tingkat depresi pada mahsiswa dengan usia 18-22 tahun dikarenakan tingginya tingkat penggunaan media sosial (Anggraini, 2015:1). Penelitian lainnya dari Shensa, Sidani, Dew, Escobar-Viera, \& Primack, (2018:123) juga menemukan bahwa seringnya mengunakan media sosial berkaitan erat dengan tingginya tingkat depresi dan kecemasan pada orang dewasa dengan rentang usia 19 -34 tahun. Oleh sebab itu, penelitian ini dirancang dengan tujuan untuk mengungkapkan seberapa besar tingkat depresi pada mahasiswa dan hubungannya dengan intensitas penggunaan media sosial pada mahasiswa.

\section{Media Sosial}

Kaplan \& Haenlein (Sulianta, 2015: 5-6) menjelaskan bahwa media sosial adalah kelompok aplikasi berbasis internet yang dibangun atas dasar ideologi dan teknologi web versi 2.0 yang mungkin terciptanya website yang interaktif. Media sosial merupakan media online yang memungkinkan bagi penguna untuk berpartisipasi, saling berbagi, dan menciptakan isi di dalamnya (Cahyono, 2016:140). Dapat dikatakan media sosial adalah media interaksi sosial antar manusia dalam memproduksi, berbagi dan bertukar informasi yang mencakup gagasan dan berbagai konten dalam komunitas virtual (Ahlqvist, et.al, dalam Sulianta, 2015:5).

Intensitas penggunaan media sosial merupakan kuantitas perhatian dan ketertarikan seseorang dalam menggunakan media sosial dilihat dari kedalam atau kekuatannya dalam menggunakan media sosial. Teori yang mendasari penggunaan media sosial adalah Uses and Gratification Theory (UGT) atau teori penggunaan dan pemenuhan kepuasaan. Dalam teori UGT dijelaskan bahwa perilaku penggunaan media sosial didasarkan pada adanya keinginan untuk memenuhi kepuasan atau kebutuhan si pengguna. Kebutuhan atau keinginan berkaitan dengan tujuan penggunaan media sosial (Sartika, 2019: 38). Konsep pemenuhan kebutuhan dalam media sosial mencakup di dalamnya terdapat dua indikator, yaitu kualitas dan kuantitas intensitas penggunaan media sosial (Olufadi, 2016:454). Teori lainnya yang melandasi penggunaan media sosial adalah Technology Acceptance Model (TAM) ditentukan oleh dua keyakinan yaitu perceived usefulness (PU) dan perceived ease of use (PEU). Berdasarkan teori tersebut diketahui bahwa pengguna media sosial memilih untuk menggunakan media sosial dikarenakan media sosial merupakan sarana yang mudah dan berguna bagi mereka (Olufadi, 2016: 455). PEU dan PU dapat berpotensi mempengaruhi rendah atau tingginya frekuensi intensitas penggunaan media sosial. Maka aspek intensitas penggunaan media sosial dapat dilihat pada dalamnya perhatian dan penghayatan ketika menggunakan media sosial serta banyak jumlah durasi dan frekeuensi dalam 
menggunakan media sosial (Del Barrio dalam Erma, 2012:87).

\section{Depresi}

Mengalami depresi merupakan hal yang pasti dapat terjadi pada manusia. Masa depresi adalah masa terganggunya fungsi manusia yang berkaitan dengan perasaan sedih (Kaplan,2010: 20). Berdasarkan konsep teori Beck (1967:6) depresi merupakan terjadinya perubahan yang spesifik pada suasana hati dengan perubahan menuju ke negatif (sedih, kecewa), munculnya konsep diri yang negatif, munculnya keinginan menghukum diri sendiri, terjadinya kemunduran dalam diri, terjadinya perubahan pada fungsi vegetatif tubuh, dan adanya perubahan dalam tingkat aktivitas yaitu mengalami kemunduran dalam beraktivitas atau mengalami peningkatan yang tidak wajar. Secara rinci Gerald C. Davidson (2004:372) menyebutkan bahwa depresi adalah kondisi emosional seseorang yang menunjukan kesedihan yang amat sangat, perasaan tidak berarti dan bersalah yang ditandai dengan menarik diri, tidak dapat tidur, putus asa terhadap masa depan, dan kehilangan selera terhadap aktivitas sehari-hari. Berdasarkan PPDGJ III (Maslim, 2013: 64) episode depresif terbagi menjadi depresif ringan, sedang dan berat. Masing-masing memiliki kriteria diagnosis yang berbeda-beda.

Depresi dapat disebabkan oleh faktor biologis, psikologis, dan sosialekonomi. faktor biologis dapat berupa abnormalitas neuro bilogis (King 2014: 313), permasalahan pada hormon (Durand \& Barlow 2006: 298), dan genetik dengan cara mempengaruhi tingkat serotonin dan saraf penghantar lainnya yang terdapat di otak (King, 2014: 313). Adapun penyebab psikologis dari depresi adalah distrosi kognitif yaitu kecenderungan untuk menginterpretasikan kejadian-kejadian sehari-hari dengan presepsi yang terdistorsi (Beck, 1967: 234). Komponen utama yang terdistorsi dalam kognitif adalah pandangan terhadap diri sendiri, pandangan terhadap masa yang akan datang, dan pandangan terhadap pengalaman hidup. Semua pandangan tersebut cenderung mengarah kepada pandangan negatif. Sedangkan faktor sosial berupa permasalahan dalam hubungan sosial. Menurut Priest (1987: 25) hubungan pergaulan yang tak manis merupakan salah satu sumber umum munculnya depresi pada seseorang. Selain itu faktor sosial-ekonomi juga mempengaruhi keadaan depresi seseorang. Individu dengan status sosio ekonomi rendah akan lebih rentan terhadap depresi daripada indvidu yang memiliki status tinggi (King, 2014:319).

Menurut Aaron Beck (1967:42) aspek-aspek depresi seseorang dapat dilihat pada emosional, kognitif, motivasi, dan fungsi vegetatif. Aspek emosional mengacu pada perubahan perasaan atau perilaku yang tampak pada suasana hati dengan kondisi sedih, munculnya perasaan negatif terhadap diri sendiri, kurangnya rasa puas, hilangnya kelekatan dengan orang lain, terdapat kecenderungan untuk menangis di luar kemauan, dan hilangnya respon kegembiraan. Sedangkan aspek kognitif dapat berupa rendahnya evaluasi diri, selalu menyalahkan diri sendiri, terbayang-bayang hal negatif di masa depan, citra tubuh yang terdistorsi, dan ragu-ragu dalam mengambil keputusan. Aspek motivasi berkaitan dengan kaku dalam berkeinginan, mengasingkan diri atau menghindari orang lain dan segala aktivitas, keinginan untuk bunuh diri, dan peningkatan ketergantungan terhadap orang lain. Adapun kehilagan nafsu makan, kehilangan gairah seks, mengalami gangguan tidur, dan merasakan lelah yang sangat merupakan bentuk dari adanya gangguan fungsi vegetatf atau gangguan fisik.

\section{Mahasiswa}

Mahasiswa merupakan insan-insan calon sarjana yang terlibat dengan perguruan tinggi, dididik dan di harapkan untuk menjadi calon-calon intelektual (Tangkudung 2014:3). Mahasiswa merupakan suatu kelompok dalam 
masyarakat yang memperoleh statusnya karena ikatan dengan perguruan tinggi dan calon intelektual atau cendekiawan muda dalam suatu lapisan masyarakat yang sering kali syarat dengan berbagai predikat (Ebtanastiti \& Muis, 2014: 5). Mahasiswa dikategorikan pada tahap perkembangan usia 18 sampai 25 tahun. Tahap ini dapat digolongkan pada masa remaja akhir sampai dengan dewasa awal (Hulukati \& Djibran, 2018: 74). Menurut Mar'at (2009:233) masa tersebut mengalami perkembangan pada fisik, kognitif, dan psikososial. Perkembangan fisik pada masa remaja akhir sampai dewasa awal ditandai dengan memuncaknya kemampuan dan kesehatan fisik. Mulai dari berkembangnya kekuatan fisik yang menjadi kuat dan cepat, sampai pada kualitas reproduksi yang maksimal. Pada perkembangan kognitif di masa remaja akhir dan usia dewasa awal berada pada tahap proses berpikir postformal yaitu cara berpikir yang reflektif, realistis, pragmatis dan bervariasi dalam memecahkan berbagai permasalahan. Perkembangan psikososial di masa remaja akhir dan usia dewasa awal ditandai adanya eksplorasi relasi (Santrock, 2012:6). Berdasarkan teori tahap perkembangan Erik Erikson, masa dewasa awal merupakan tahap yang berfokus bukan lagi pada individu melainkan hubungan indvidu dan dengan perasaannya terhadap orang lain (Salkind, 2010: 201). Pada masa tersebut terdapat keinginan untuk memiliki hubungan yang akrab atau intim dengan sosialnya. Orang-orang dalam masa tersebut siap untuk mengembangkan kemampuan yang dibutuhkan untuk menciptakan hubungan akrab atau intim dengan orang lainnya. Hubungan akrab atau intim dengan orang lain dalam masa ini merupakan hal yang penting. Melihat karakterisitik perkembangan mahasiswa yang berada dalam masa remaja akhir sampai dewasa awal sedang mengalami ekplorasi dalam dunia relasi dan individu dengan cara mencari jaringan sosial sampai membangun hubungan sosial yang lebih erat atau intim. Maka wajar apabila pengguna media sosial didominasi oleh mahasiswa, karena salah satu fungsi fasilitas yang disediakan oleh media sosial adalah memudahkan dalam membentuk hubungan sosial yang lebih erat atau intim.

Hubungan Intensitas Penggunaan Media Sosial dan Depresi

Intensitas penggunaan atau konsumsi media sosial berkaitan dengan tingkat depresi seseorang. Hal tersebut disebabkan adanya permasalahan dalam penggunaan media sosial sehingga memicu munculnya gejala depresi. Permasalahan tersebut diantaranya adalah cyberbullying dan perasaan insecure. Depresi dapat muncul karena timbulnya permasalahan hubungan sosial di media sosial dan adanya sikap membandingkan diri dengan pengguna lain di media sosial sehingga memunculkan pandagan negatif terhadap diri sendiri atau perasaan insecure dan menjelekan diri.

Salah satu faktor penyebab depresi adalah faktor psikososial yang terdiri dari faktor psikologis dan sosial. Salah satu faktor psikologis dari timbulnya depresi adalah distorsi kogntif. Distorsi kognitif merupakan pandangan negatif terhadap diri sendiri, pengalaman yang di dapatkan dan masa yang akan datang. Diantara bentuk dari distorsi kogntif adalah membandingkan diri sendiri secara tidak adil dengan orang lain. Sedangkan melalui media sosial peluang untuk membandingkan diri dengan orang lain begitu terbuka.

Di media sosial setiap pengguna bebas untuk mengunggah konten sesuai dengan keinginan masing-masing. Media sosial memberikan kesempatan untuk semua penggunanya membagikan konten dalam bentuk foto, video, maupun tulisan. Selain itu, media sosial merupakan sarana yang sempurna untuk menampilkan atau menunjukan kebolehan diri. Pengguna media sosial secara selektif memilih konten yang akan disebarkannya agar sesuai dengan citra diri ideal menurut masing-masing pengguna (Rosenberg \& Egbert, 2011:1). 
Konten dalam media sosial dapat dilihat oleh siapa pun sesuai dengan kehendak pemilik konten.

Munculnya perbandingan diri dengan orang lain berasal dari melihat konten pengguna lainnya kemudian membandingkan dengan konten sendiri atau dengan keadaan diri sendiri. Perbandingan yang muncul adalah perbandingan antara kelemahan diri dengan kelebihan yang dimiliki oleh pengguna media sosial lainnya (Vogel, Rose, Roberts, \& Eckles, 2014: 207).

Perbandingan sosial tidak hanya berpengaruh agar seseorang dapat mengevaluasi diri sendiri, akan tetapi dalam perbandirngan sosial, seseorang dapat mengalami tekanan untuk lebih memajukan diri sesuai dengan yang dibandingkan (Hui, Chua, \& Chang, 2016: 191). Meskipun perbandingan sosial dapat memacu perbaikan diri dengan menjadi lebih baik dari yang dibandingkan, namun perbandigan sosial lebih sering menyebabkan orang merasa rendah diri atau insecure, dan menilai diri sendiri dengan pandangan negatif (Vogel et al., 2014: 207). Maka dampak memandingkan diri tersebut akan menciptakan pandangan negatif terhadap diri sendiri. Sedangkan pandangan negatif terhadapa diri sendiri merupakan salah satu sebab psikologis timbulnya depresi.

Media sosial juga merupakan sarana bagi orang-orang dari berbagai tempat untuk berkumpul dan bersosialisasi. Melalui media sosial, seseorang dapat menciptakan relasi akrab antar indvidu atau antara individu dengan kelompok. Sebaliknya, media sosial juga dapat menjadi sarana timbulnya permasalahan dalam hubungan sosial (Anwar, 2017:142). Cyberbullying dan cyberbate merupakan contoh dari adanya permasalahan dalam hubungan sosial yang muncul di media sosial. Cyberbullying merupakan suatu bentuk bullying yang terjadi secara online melalui media sosial (Anwar, 2017: 141). Adapun cyberhate merupakan tindakan, pernyataan yang menyerukan kekerasan, atau serangan verbal yang berkaitan dengan agama, etnis, jenis kelamin, orientasi seksual, dll pada seseorang atau kelompok (Hanzelka \& Schmidt, 2017:146). Keduanya sama-sama memiliki dampak pada depresi, dikarenakan keduanya merupakan permasalahan dalam hubungan sosial, sedangkan salah satu factor sosial yang menyebabkan depresi adanya permasalahan dalam hubungan sosial.

Penelitian Shensa et.al (2018:117) menunjukkan bahwa peningkatan konsumsi media sosial dapat menyebabkan adanya pengalaman negatif dalam dunia maya. Artinya semakin tinggi penggunaan media sosial maka semakin tinggi pula peluang untuk mendapatkan pengalaman negatif di media sosial. Diantara pengalaman negatif tersebut adalah masalah interaksi sosial dalam hubungan di media sosial yang mengarahkan pada depresi. Hasil penelitian Weidman et.al (Shaw, A. M., Timpano, K. R., Tran, T. B., \& Joormann, J., 2015:575) menunjukkan bahwa kecenderungan untuk berinteraksi secara online atau berinteraksi intens di media sosial berkaitan dengan timbulnya gejala depresi. Sejalan dengan penelitian Shaw (Seabrook, 2016:50) yang menemukan bahwa gejala depresi berkorelasi positif dengan komunikasi yang interaktif di media sosial. Aktivitas lainnya yang intens di media soial yang berkaitan dengan depresi adalah produksi konten. Penelitian Park, S., Inyeop K., Sang W.L., Jaehyun Y., Bumseok J., \& Meeyoung C (2015: 557) membuktikan bahwa individu yang mengalami depresi akut (atau peningkatan relatif dalam tingkat keparahan gejala depresi), mengalami peningkatan frekuensi produksi konten di media sosial selama 6 bulan. Hal tersebut sejalan dengan penelitian Shaw (Seabrook, 2016:50) yang menemukan bahwa gejala depresi berkorelasi positif dengan produksi konten yang lebih sering. Produksi konten yang lebih sering dapat mengarahkan pengguna media sosial untuk saling mengamati dan bersaing dalam menghasilkan konten 
sehingga timbul perbandingan diri dengan pengguna media sosial lainnya yang seringkali mengarahkan pada pandangan negatif terhadap diri sendiri yang berlebihan (Vogel et al., 2014: 207). Intensitas tinggi dalam produksi konten dan komunikasi aktif di media sosial menandakan adanya intensitas tinggi dalam penggunaan media sosial. Maka intensitas tinggi dalam penggunaan media sosial secara tidak langsung dapat berisiko pada tingginya tingkat depresi. Berdasarkan uraian diatas, maka hipotesis yang diajukan dalam penelitan ini yaitu adanya hubungan positif antara intensitas penggunaan media sosial dengan tingkat depresi pada mahasiswa.

\section{Metode Penelitian}

Jenis penelitian yang digunakan untuk mendesain penelitian ini adalah penelitian ex post facto dengan pendekatan kuantitatif. Adapun metode yang digunakan dalam pendekatan analisis hasil penelitian ini adalah metode korelasional. Penelitian dilaksanakan di Fakultas Ilmu Pendidikan Universitas Negeri Yogyakarta (FIP UNY). Penelitian dilaksanakan dalam jangka waktu tujuh bulan, yaitu dimulai pada tanggal September 2019 - Maret 2020.

Populasi dalam penelitian ini adalah mahasiswa angkatan 2017 sebanyak 810 orang. Jumlah sampel yang diambil dari populasi dihitung berdasarkan tabel Krejcie dan Morgan sebanyak 250 mahasiswa. Teknik pengambilan sampel menggunakan teknik accidental sampling yang merupakan teknik pengambilan sampel berdasarkan kebetulan bertemu dengan peneliti yang sesuai dengan kriteria subyek yang dibutuhkan (Sugiyono, 2009:85).

Teknik pengumpulan data dilakukan melalui angket atau kuesioner yang mengukur tingkat depresi pada mahasiswa dan intensitas mahasiswa dalam menggunakan media sosial. Secara garis besar angket dibagi menjadi tiga bagian. Bagian pertama terdiri dari data demografi subjek. Bagian kedua merupakan skala pengukuran intensitas penggunaan media sosial. Bagian ketiga merupakan skala pengukuran tingkat depresi pada mahasiswa. Angket menggunakan skala likert sebagai pilihan respons dari subjek. Instrumen yang digunakan untuk mengukur intensitas penggunaan media sosial adalah instrumen yang diadaptasi dari instrumen rancangan Sylvia Marini (2020:116) dalam tesis yang berjudul Interaksi Peer Group dan Intensitas Penggunaan Media Sosial Terhadap Cyberbullying Remaja. Instrumen tersebut telah melakukan uji diskriminasi aitem dan dinyatakan memenuhi kriteria fungsi ukur skala dan memiliki reliabilitas kuat dengan koefisien Cronbach Alpha sebesar 0,776. Adapun instrumen yang digunakan untuk mengukur tingkat depresi pada mahasiswa menggunakan Beck Depression Inventory (BDI-II) yang terbukti valid dalam mengukur gejala depresi (Dieris-Hirche et al., 2017:98). Hasil perhitungan validitas instrumen BDI-II menunjukkan bahwa instrumen memiliki sensitivitas yang bagus dan spesifik dalam mendeteksi depresi (Wang \& Gorenstein, 2013:416). BDI-II memiliki tingkat reliabilitas yang sangat kuat dengan koefisien Cronbach Alpha sebesar 0,889 .

Penelitian ini menggunakan teknik analisis data korelasional yang bertujuan untuk melihat ada atau tidaknya hubungan antara dua variabel yang dipasangkan. Sebelum melakukan uji hipotesis terlebih dahulu dilaksanakannya analisis data deksriptif untuk mendeskripsikan data mengenai variabel yang sedang diteliti yang diperoleh dari kelompok subjek penelitian. Melalui analisis deskriptif, skala yang ada dalam instrumen pengukuran tingkat depresi maupun intensitas penggunaan media sosial akan diterjemahkan ke dalam bentuk interval. Peneliti membagi 3 kategori interval variabel menjadi tinggi, sedang dan rendah.

Dalam menguji hipotesis terlebih dahulu diharuskan menggunakan uji prasyarat yang terdiri dari uji normalitas dan uji linearitas. Uji normalitas dilakukan untuk 
melihat data yang dihasilkan berdistribusi normal atau tidaknya (Priyatno, 2013:13). Jika data berdistribusi normal maka analisis yang digunakan adalah statistik parametrik. Pengujian normalitas data dilakukan dengan uji Kolmogorov-Smirnovtest yang memiliki taraf signifikansi $5 \%$ atau 0,05. Data dikatakan terdistribusi normal jika mencapai taraf signifikansi $\geq 0,05$. Sebaliknya data dikatakan tidak terdistribusi normal jika taraf signifikasnsi $\leq 0,05$ (Priyatno, 2013:13). Sedangkan uji linearitas dilakukan untuk mengetahui ada atau tidaknya hubungan linearitas diantara dua variabel yang sedang diteliti. Hubungan yang linear menunjukkan bahwa rata-rata yang diperoleh dari kelompok data sampel terletak dalam garis-garis lurus. Jika kedua variabel memiliki hubungan yang linear maka variable tergantung secara linear akan mengalami kenaikan atau penurunan menyesuaikan dengan variable bebas apabila mengalami kenaikan atau penurunan. Uji linearitas dilakukan dengan Tes for Linearity melalui program SPSS Statistics for windows yang memiliki taraf signifikan sebesar 0.05. Hubungan antar variabel dikatakan linear apabila taraf signifikansi $\geq 0,05$. Selanjutnya, uji hipotesis dilakukan dengan analisis korelasi Product Momen. Uji hipotesis dilakukan untuk mengetahui status hipotesis penelitian yang diajukan ditolak atau diterima. Hipotesis yang diajukan dalam penelitian ini dinyatakan adanya hubungan positif yang signifikan antara intensitas penggunaan media sosial dengan tingkat depresi pada mahasiswa. Hipotesis diterima apabila nilai signifikansi pada korelasi product momen $\leq$ 0,05 .

\section{Hasil Penelitian dan Pembahasan}

Berdasarkan hasil pengumpulan data diketahui bahwa responsden dengan jenis kelamin perempuan lebih dominan dibandingkan responsden dengan jenis kelamin laki-laki. Jumlah responsden wanita sebanyak 203 mahasiswa sedangkan responsden laki-laki berjumlah 47 mahasiswa. Setengah dari total responsden memiliki usia 20 tahun, sisanya berusia 19 , 21, 23, dan 24 tahun. Namun responsden yang berusia 24 tahun hanya berjumlah 1 orang. Kebanyakan responsden merupakan mahasiswa program studi Pendidikan Guru Sekolah Dasar (PGSD) dengan total sebanyak 82 responsden. Lebih jelasnya dapat dilihat pada diagram berikut ini:

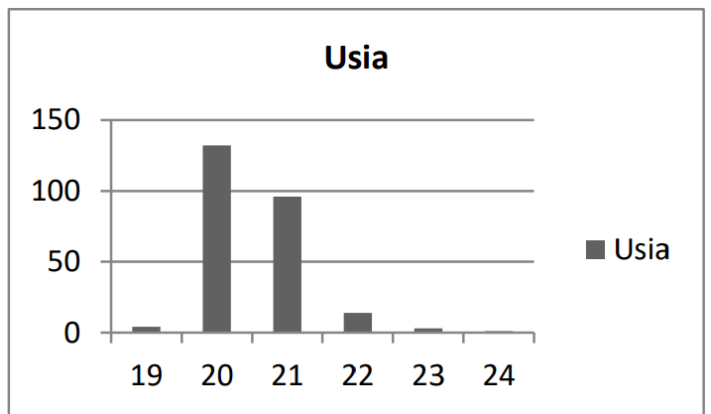

Gambar 1. Diagram Usia Subyek

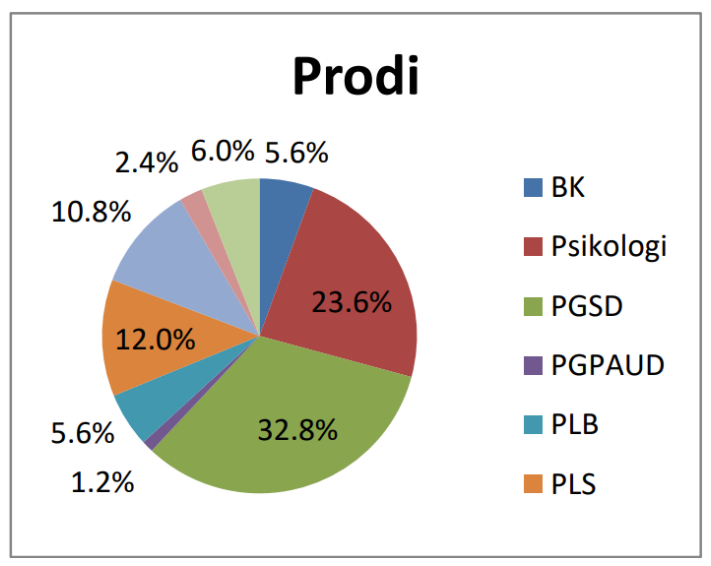

Gambar 2. Diagram Program Studi Subyek

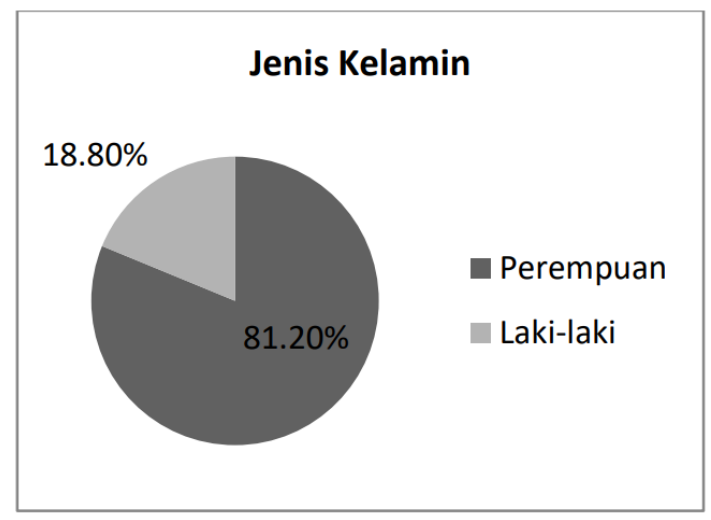

Gambar 3. Diagram Jenis Kelamin Subjek 
Mayoritas responden menggunakan media sosial yang berbeda lebih dari 3 jenis. Sedangkan pengguna yang menggunakan satu jenis media sosial diketahui hanya sebanyak 4 responsden. Dengan presentase 1.6 persen. Adapun pengguna yang hanya menggunakan 3 jenis media sosial lebih banyak daripada pengguna yang hanya menggunakan 2 jenis media sosial. jumlah pengguna yang hanya menggunakan 3 jenis media sosial sebanyak 27 responsden atau 10.8 persen, sedangkan jumlah pengguna yang hanya menggunakan 2 jenis media sosial sebanyak 14 responsden atau 5.6 persen. Media sosial yang paling banyak digunakan adalah WA (Whatsapp). Hampir seluruh responsden menggunakan WA. Hal tersebut dilihat dari jumlah frekuensi pengguna WA sebanyak 249 dari total responsden sebanyak 250 orang. Jenis media sosial lainnya setelah WA yang paling banyak digunakan adalah Instagram, Youtube, Twitter, Facebook dan LINE.

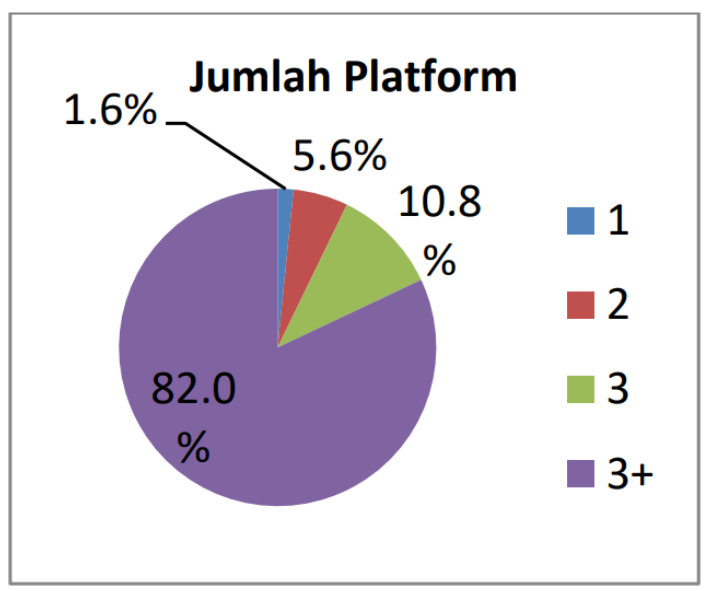

Gambar 4. Diagram Jumlah Platform yang Digunakan

Variabel intensitas penggunaan media sosial memiliki nilai minimum 18,00 dan nilai maksimum 53,00 dengan nilai ratarata-rata 35,5760 (tabel 1). Rata-rata representative skor pada data intensitas penggunaan media sosial mean data sebesar 5,9491, median sebesar 5,9161, dan modus sebesar 5,92 (tabel 2). Hasil tersebut menunjukkan bahwa data terdistribusi normal dikarenakan seluruh skor menunjukkan hasil yang sama.

Adapun variabel tingkat depresi diketahui memiliki nilai minimum 0,00 dan nilai maksimum 44,00 dengan nilai rata-rata sebesar 12,3680 (tabel 1). Skor representative menunjukan bahwa mean data tingkat depresi sebesar 3,2802, median sebesar 3,3166, dan modus sebesar 3,74 (tabel 3). Hasil tersebut menunjukkan bahwa data terdistribusi normal.

Tabel 1. Data Statistik Variabel

\begin{tabular}{lccccc}
\hline & $\mathrm{N}$ & $\begin{array}{c}\text { Mi } \\
\mathrm{n}\end{array}$ & $\begin{array}{c}\text { Ma } \\
\mathrm{x}\end{array}$ & Mean & $\begin{array}{c}\text { Std. } \\
\text { Deviatio } \\
\mathrm{n}\end{array}$ \\
\hline $\begin{array}{l}\text { Intensitas } \\
\begin{array}{l}\text { Pengguna } \\
\text { an Media } \\
\text { Sosial }\end{array}\end{array}$ & 250 & 18 & 53 & 35,5 & 5,0 \\
\hline $\begin{array}{l}\text { Tingkat } \\
\text { depresi }\end{array}$ & 250 & 0 & 44 & 12,3 & 8,67 \\
\hline $\begin{array}{l}\text { Valid N } \\
\text { listwise) }\end{array}$ & 250 & & & & \\
\hline
\end{tabular}

Tabel 2. Rata-rata Representasi Skor Intensitas Penggunaan Media Sosial

\begin{tabular}{llll}
\hline & Mean & Median & Modus \\
\hline Intensitas & 5,9491 & 5,9161 & 5,92 \\
Penggunaan & & & \\
Media & & & \\
Sosial & & & \\
\hline
\end{tabular}

Tabel 3. Rata-Rata Representasi Skor Tingkat Depresi

\begin{tabular}{llll}
\hline & Mean & Median & Modus \\
\hline Intensitas & 3,2802 & 3,3166 & 3,74 \\
Penggunaan & & & \\
Media & & & \\
Sosial & & & \\
\hline
\end{tabular}

Berdasarkan hasil perhitungan distribusi data intensitas penggunaan media sosial diketahui bahwa mayoritas 
responsden menggunakan media sosial dalam tingkat intensitas sedang. Hal tersebut dilihat pada jumlah frekuensi kategori sedang sebanyak 195 dengan presentasi $78 \%$. Adapun responsden yang menggunakan media sosial dengan intensitas dalam kategori tinggi sebanyak 32 atau $12,8 \%$. Sedangkan responsden yang menggunakan media sosial dalam kategori rendah hanya sebanyak 23 orang atau dengan prestasi $9,2 \%$.

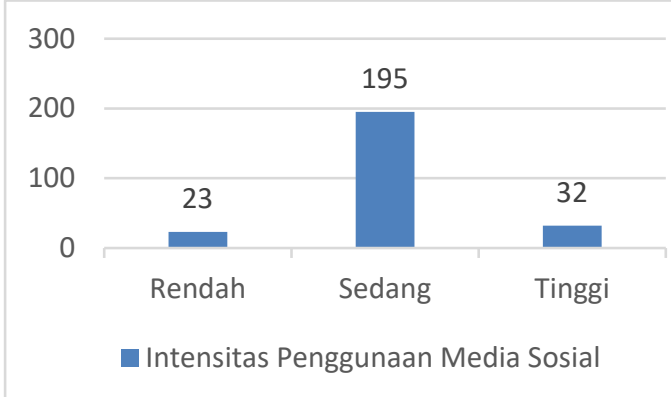

Gambar 6. Diagram Interval Intensitas Penggunaan Media Sosial

Mayoritas tingkat depresi responden berada pada kategori sedang. Berdasarkan hasil perhitungan distribusi data tingkat depresi diketahui bahwa responsden yang memiliki tingkat depresi tinggi sebanyak 41 orang atau sekitar 16,4\% dari total responsden. Responsden yang memiliki tingkat depresi sedang sebanyak 175 orang atau sebanyak $70 \%$. Adapun responsden yang memiliki tingkat depresi rendah sebanyak 34 orang atau 13,6\%.

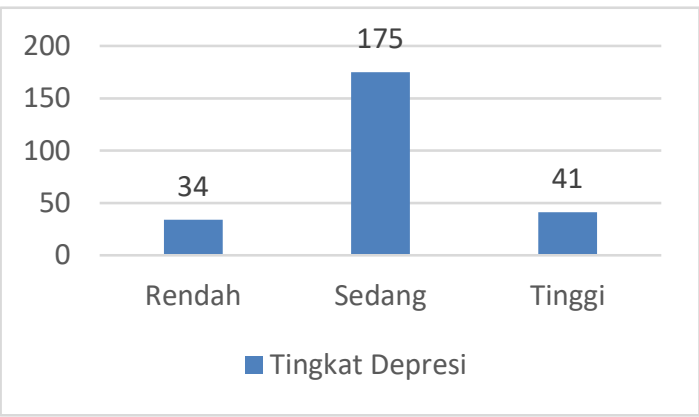

Gambar 6. Diagram Interval Tingkat Depresi

Hasil uji normalitas data menunjukkan bahwa data terdistribusi normal. Berdasarkan hasil analisis
Kolmogorv Sminovr, diketahui bahwa nilai signifikansi sebesar $0,200(p=0,200)$ yang menandakan bahwa nilai signifikansi lebih besar dari 0,05.

Begitu pula dengan hasil uji linearitas menunjukkan bahwa hubungan antara variabel merupakan hubungan yang linear. Berdasarkan hasil pengujian linearitas dengan test of linearity yang dibantu oleh IBM SPSS For Windows 23.0 Version, didapatkan bahwa nilai signifikansi pada Deviation From Linearity sebesar 0,194. Hasil tersebut menunjukkan bahwa nilai signifikansi lebih besar dari 0,05. Maka dapat disimpulkan bahwa variabel tingkat intensitas penggunaan media sosial memiliki hubungan yang linear dengan variabel tingkat depresi. Selanjutnya, hasil hipotesis menunjukkan bahwa terdapat hubungan positif dan signifikan antara intensitas penggunaan media sosial dan tingkat depresi pada mahasiswa.

Berdasarkan hasil uji korelasi product moment didapatkan nilai signifikansi (p) antara variabel intensitas penggunaan media sosial dan tingkat depresi sebesar 0,02 . Nilai signifikansi tersebut diketahui lebih kecil daripada 0,05 maka dapat dinyatakan bahwa terdapat korelasi atau hubungan antara intensitas penggunaan media sosial dengan tingkat depresi. Adapun nilai korelasi Pearson antara intensitas penggunaan media sosial dan tingkat depresi sebesar 0,147 (tabel 4). Nilai tersebut menunjukan nilai dengan bilangan positif yang berarti terdapat hubungan positif antara intensitas penggunaan media sosial dan tingkat depresi.

Mayoritas mahasiswa angkatan 2017 di Fakultas Ilmu Pendidikan Universitas Negeri Yogyakarta kurang memenuhi karakteristik dalam aspek intensitas penggunaan media sosial. Hal tersebut dikarenakan mayoritas mahasiswa menggunakan media sosial dalam kategori intensitas yang sedang. Adapun kategori intensitas sedang tidak memiliki perhatian yang tinggi terhadap media sosial, tidak memiliki pengahyatan terhadap informasi 
yang ada di media sosial, tidak berdurasi lebih dari 3 jam ketika menggunakan media sosial dalam sehari, dan tidak lebih dari 4 kali pengunaan media sosial perharinya.

Tabel 4. Hasil Uji Hipotesis

\begin{tabular}{|c|c|c|c|}
\hline \multicolumn{4}{|c|}{ Correlation } \\
\hline & & $\begin{array}{l}\text { Intensitas } \\
\text { Penggunaan } \\
\text { Sosial Media }\end{array}$ & $\begin{array}{l}\text { Tingkat } \\
\text { Depresi }\end{array}$ \\
\hline \multirow{3}{*}{$\begin{array}{l}\text { Intensitas } \\
\text { Penggunaan } \\
\text { Media } \\
\text { Sosial }\end{array}$} & $\begin{array}{c}\text { Pearson } \\
\text { Correlation }\end{array}$ & 1 & $0,147^{*}$ \\
\hline & $\begin{array}{l}\text { Sig (2- } \\
\text { tailed) }\end{array}$ & & 0,020 \\
\hline & $\mathrm{N}$ & 250 & 250 \\
\hline \multirow[t]{3}{*}{$\begin{array}{l}\text { Tingkat } \\
\text { Depresi }\end{array}$} & $\begin{array}{c}\text { Pearson } \\
\text { Correlation }\end{array}$ & $0,147^{*}$ & 1 \\
\hline & $\begin{array}{l}\text { Sig (2- } \\
\text { tailed) }\end{array}$ & 0,020 & \\
\hline & $\mathrm{N}$ & 250 & 250 \\
\hline
\end{tabular}

Kebanyakan mahasiswa angkatan 2017 di Fakultas Ilmu Pendidikan Universitas Negeri Yogyakarta memiliki depresi pada tingkatan sedang. Pada kategori tersebut setidaknya ada 2 gejala utama yang dialami. Gejala utama dapat berupa afek depresi, kehilangan minat atau kegembiraan, dan berukurangnya energi yang mengarah pada menurunnya tingkat aktivitas serta perasaan mudah lelah. Selain gejala utama, penderita depresi sedang setidaknya juga mengalami 3 atau 4 gejala lainnya. Gejala tersebut dapat berupa, konsentrasi atau perhatian berkurang, kurangnya kerpercayaan diri, merasa tidak bergunan atau bersalah, pesimis terhadap masa depan, keinginan untuk membahayakan diri sendiri atau bunuh diri, tidur yang terganggu, dan nafsu makan berkurang. Hasil penelitian menggambarkan bahwa terdapat hubungan positif antara intensitas penggunaan media sosial dengan tingkat depresi pada mahasiswa angkatan 2017 Fakultas Ilmu Pendidikan Universitas Negeri Yogyakarta. Artinya, semakin tinggi intensitas penggunaan media sosial maka cenderung akan semakin tinggi pula tingkat depresi. Hasil tersebut serupa dengan penelitian O'Keeffe (2011:802) yang menyatakan bahwa pengguna media sosial yang menghabiskan banyak waktu untuk mengakses situs media sosial akan mulai menunjukkan adanya gejala-gejala depresi. Hal tersebut dapat terjadi karena semakin lama menggunakan media sosial maka akan semakin lama pengguna melihat berbagai macam hal atau informasi yang ada di media sosial. Infromasi dalam media sosial bermacam-macam yang di dalamnya terdapat berbagai konten yang mengandung sifat berbeda-beda. Konten di media sosial juga dibuat oleh pengguna media sosial lainnya. Depresi dapat timbul karena melihat berbagai konten yang ada di media sosial. Melihat konten yang diunggah oleh pengguna media sosial lainnya dapat memicu depresi karena timbulnya perbandingan diri dengan konten yang telah dilihatnya tersebut. Sebagaimana yang diketahui dalam teori Aaron Beck, bahwasanya penyebab timbulnya depresi karena adanya kognitif yang terdistorsi. Distorsi kognitif merupakan pandangan negatif terhadap diri sendiri, pengalaman yang didapatkan dan masa yang akan datang. Diantara bentuk dari distorsi kogntif adalah membandingkan diri sendiri secara tidak adil dengan orang lain. Sedangkan melalui media sosial peluang untuk membandingkan diri dengan orang lain begitu terbuka. Di media sosial setiap pengguna bebas untuk mengunggah konten sesuai dengan keinginan masing-masing. Media sosial memberikan kesempatan untuk semua penggunanya membagikan konten dalam bentuk foto, video, maupun tulisan. Selain itu, media sosial merupakan sarana yang sempurna untuk menampilkan atau menunjukan kebolehan diri. Pengguna media sosial secara selektif memilih konten yang akan disebarkannya agar sesuai dengan citra diri ideal menurut masing-masing pengguna (Rosenberg \& Egbert, 2011:1). Konten dalam media sosial dapat dilihat 
oleh siapa pun sesuai dengan kehendak pemilik konten. Munculnya perbandingan diri dengan orang lain berasal dari melihat konten pengguna lainnya kemudian mengarah kepada membandingkan dengan konten sendiri atau dengan keadaan diri sendiri yang berbeda dari yang telah dilihat. Menurut Vogel (2014: 207) Perbandingan yang muncul dalam media sosial adalah perbandingan antara kelemahan diri dengan kelebihan yang dimiliki oleh pengguna media sosial lainnya. Perbandingan dapat mengarahkan seseorang untuk mengevaluasi diri sendiri, akan tetapi melalui perbandirngan, seseorang dapat mengalami tekanan untuk memajukan diri sesuai dengan yang dibandingkan (Hui, Chua, \& Chang, 2016: 191). Meskipun perbandingan dapat memacu perbaikan diri untuk menjadi lebih baik dari yang dibandingkan, namun perbandigan lebih sering menyebabkan merasa rendah diri atau insecure, dan menilai diri sendiri dengan pandangan negatif (Vogel et al., 2014: 207). Maka dampak memandingkan diri dapat menciptakan pandangan negatif terhadap diri sendiri, sedangkan pandangan negatif terhadap diri sendiri merupakan salah satu sebab psikologis timbulnya depresi. Selain membandingkan diri, depresi dapat dipicu dengan adanya permasalahn dalam hubungan sosial. Menurut Priest (1987: 25) hubungan pergaulan yang tak manis merupakan salah satu sumber umum munculnya depresi pada seseorang. Seperti yang telah diketahui bahwa medi sosial merupakan media yang di dalamnya tercipta interaksi sosial sehingga menghasilkan adanya hubungan sosial. Media sosial merupakan sarana bagi orang-orang dari berbagai tempat untuk berkumpul dan bersosialisasi. Melalui media sosial, seseorang dapat menciptakan relasi akrab antar indvidu atau antara individu dengan kelompok. Sebaliknya, media sosial juga dapat menjadi sarana timbulnya permasalahan dalam hubungan sosial (Anwar, 2017:142). Cyberbullying dan cyberhate merupakan contoh dari adanya permasalahan dalam hubungan sosial yang muncul di media sosial. Cyberbullying merupakan suatu bentuk bullying yang terjadi secara online melalui media sosial (Anwar, 2017: 141). Adapun cyberhate merupakan tindakan, pernyataan yang menyerukan kekerasan, atau serangan verbal yang berkaitan dengan agama, etnis, jenis kelamin, orientasi seksual, dll pada seorang indvidu atau kelompok (Hanzelka \& Schmidt, 2017:146). Dua hal tersebut adalah kasus yang mendukung timbulnya permasalahan dalam hubungan sosial. Sumbangan efektif variabel intensitas penggunaan media sosial sebesar 2,2\% terhadap variabel tingkat depresi mahasiswa angkatan 2017 di Fakultas Ilmu Pendidikan Universitas Negeri Yogyakarta, selebihnya sumbangan sebesar $97.8 \%$ disebabkan oleh variabel lain. Terdapat variabel lainnya yang memiliki kontribusi terhadap depresi dalam penggunaan media sosial. Dalam penelitian Shensa et.al (2018:117) keterikatan perasaan dengan media sosial lebih memiliki pengaruh pada depresi daripada intensitas penggunaan media sosial. Individu yang lebih terhubung secara emosional dengan media sosial lebih rentan terhadap pengalaman negatif di media sosial, dan berisiko pada meningkatnya gejala depresi (Shensa et.al., 2018:118). Selain keterikatan emosi, perilaku akibat kecanduan media sosial juga menjadi faktor peningkatan depresi pada penggunaan media sosial. Perilaku akibat kecanduan dapat berupa mengabaikan hubungan dan tanggung jawab di dunia "nyata" (Andreassen, C.S., Billieux J, \& Griffiths M.D, 2016: 275). Pada penelitian lainnya menerangkan bahwa kategori teman pada media sosial juga merupakan salah satu variabel yang memiliki kontribusi pada depresi di media sosial. Tsai, C.-W., Shen, P.- D., \& Chiang, Y.-C. (2014:8) menemukan bahwa pengguna media sosial yang berteman dengan mantan pasanganya di media sosial cenderung memiliki tingkat keparahan depresi yang lebih tinggi daripada mereka yang tidak berteman dengan mantan 
pasangannya di media sosial. Selain itu, individu yang selektif memilih keikutsertaan group atau berteman di media sosial berisiko lebih rendah mengalami tekanan depresi dibandingkan yang tidak selektif dalam berteman di media sosial (Takahashi,Y., Uchida, C., Miyaki, K., Sakai, M., Shimbo, T., \& Nakayama T., 2009:29). Variabel lain yang berpengaruh pada depresi di media sosial adalah tujuan dalam penggunaan media sosial. Baker, J.R dan Moore S.M (2008:84) menunjukkan bahwa, pengguna situs media sosial yang bermaksud menggunakan situs untuk blogging memiliki tingkat depresi yang lebih tinggi daripada mereka yang tidak bermaksud untuk blog. Mereka yang menggunakan media sosial untuk blogging lebih sering menyalahkan diri sendiri. Maka variabel lain yang mempengaruhi tingginya tingkat depresi di media sosial diantaranya adalah tingkat keterikatan emosional dengan media sosial, perilaku akibat kecanduan media sosial, kategori teman yang dipilih di media sosial, dan tujuan penggunaan media sosial.

\section{Simpulan dan Saran}

Tingkat intensitas penggunaan media sosial dan tingkat depresi mahasiswa angkatan 2017 di Fakultas Ilmu Pendidikan Universitas Negeri Yogyakarta sebagian besar termasuk dalam kategori sedang. Hasil uji hipotesis menunjukan bahwa hipotesis yang diajukan diterima, yaitu adanya hubungan positif yang signifikan antara intensitas peggunaan media sosial dan tingkat depresi pada mahasiswa, artinya semakin tinggi tingkat penggunaan media sosial maka semakin tinggi pula tingkat depresi yang diperoleh. Depresi merupakan efek yang muncul secara tidak langsung dari penggunaan media sosial. Depresi muncul karena adanya permasalahan hubungan sosial yang terjadi melalui media sosial dan adanya sikap membandingkan diri dengan pengguna lain di media sosial yang menyebakan pandagan negatif terhadap diri sendiri atau munculya perasaan insecure dan menjelekan diri sendiri.

Saran bagi pengguna media sosial khusunya mahasiswa untuk lebih memperhatikan dan membatasi frekuensi dan durasi penggunaan media sosial. Bagi mahasiswa angakatan 2017 di Fakultas Ilmu Pendidikan Universitas Negeri Yogyakarta yang memiliki tingkat intensitas penggunaan media sosial dalam kategori sedang. Tingkat penggunaan tersebut sebaiknya untuk di pertahankan atau bahkan dikurangi. Karena peningkatan intensitas penggunaan media sosial sejalan dengan peningkatan risiko depresi.

\section{Daftar Pustaka}

Anggraini, A.P. (11 Desember 2015). Penelitian Ungkap Kaitan Media Sosial dan Depresi. Kompas.com. Diambil pada tanggal 20 Oktober 2019, dari https://lifestyle.kompas.com

Anwar, F. (2017). Perubahan dan Permasalahan Media Sosial. Jurnal Muara Ilmu Sosial, Humaniora, Dan Seni, 1(1), 137-144.

Andreassen, C.S., Billieux J, \& Griffiths MD. (2016). The relationship between addictive use of social media and video games and symptoms of psychiatric disorders: a large-scale cross-sectional study. Psychol Addict Behav, 30(2) :252- 262.

Azwar, Saifudin. (2018). Penyusunan Skala Psikologi (Edisi II). Yogyakarta: Pustaka Pelajar

Beck, Aaron T. (1967). Depression : Causes and treatment 1st ed. Philadelphia: University of Pennsylvania Press

Baker, J.R \& Moore S.M. (2008). Distress, coping, and blogging: comparing new Myspace users by their intention to blog. Cyberpsychol Behav, 11(1):81-85 
Cahyono, A.S. (2016). Pengaruh Media Sosial Terhadap Perubahan Sosial Masyarakat di Indonesia. Jurnal Publiciana, 9(1), 140-157

Davison, Gerald C. \& Neale, J. M. (2004). Abnormal psychology 9th ed. New York: Wiley

Dieris-Hirche, J., Bottel, L., Bielefeld, M., et.al. (2017). Media use and Internet addiction in adult depression: A casecontrol study. Computers in Human Behavior, 68, 96-103.

Durand, V.M., Barlow, D.H. (2006). Intisari Psikologi Abnormal (Edisi IV). Yogyakarta: Pustaka Pelajar

Ebtanastiti, D.F. \& Tamsil Muis. (2014). Survei Pilihan Karir Mahasiswa Fakultas Matematika Dan Ilmu Pengetahuan Alam Universitas Negeri Surabaya. Jurnal BK, 4(3), 3154

Erma, Anggi (2012). HubunganAntara Intensitas Menonton Sinetron Televisi Terbadap Perilaku Imitasi Gaya Hidup Artis Para Remaja. Skripsi, tidak diterbitkan, Universitas Islam Indonesia, Yogyakarta

Handikasari, Rirra Hayuning., Innawati Jusup., \& Andrew Johan. (2018). Hubungan Intensitas Penggunaan Media Sosial Dengan Gejala Depresi Mahasiswa Kedokteran (Studi Pada Mahasiswa Kedokteran Tingkat Akhir Yang Menggunakan Kurikulum Modul Terintegrasi). Jurnal Kedokteran Diponegoro, 7(2), 919934

Hanzelka, J., \& Schmidt, I. (2017). Dynamics of cyber hate in social media: A comparative analysis of anti-muslim movements in the Czech Republic and Germany. International Journal of Cyber Criminology, 11(1), 143-160.

Hui, T., Chua, H., \& Chang, L. (2016).
Computers in Human Behavior Follow me and like my beautiful sel fi es : Singapore teenage girls ' engagement in self-presentation and peer comparison on social media. Computers in Human Behavior, 55, 190 197.

Hulukati, W., \& Djibran, M. R. (2018). Analisis Tugas Perkembangan Mahasiswa Fakultas Ilmu Pendidikan Universitas Negeri Gorontalo. Bikotetik (Bimbingan Dan Konseling: Teori Dan Praktik), 2(1), 73-80.

Juditha,Christiany. (2011). Hubungan Penggunaan Situs Jejaring Sosial Facebook Terhadap Perilaku Remaja di Kota Makasar. Jurnal Penelitian IPTEKKOM, 13(1), 1-14.

Kaplan H.I, Sadock B.J, \& Grebb J.A. (2010). Sinopsis Psikiatri Jilid 2 (Terjemahan Widjaja Kusuma). Jakarta: Binarupa Aksara

Kaplan, A. M., \& Haenlein, M. (2010). Users of the world, unite! The challenges and opportunities of Social Media. Business Horizons, 53(1), 59-68.

Kemp, Simon (30 Januari 2019). Digital 2019: Global Internet Use Accelerates. Wearesocial.com. Diambil pada tanggal 25 November 2019, dari https://wearesocial.com/blog/2019 /01 /digital-2019-global-internetuseaccelerates

King, L.A. (2014). Psikologi Umum: Sebuah Pandangan Apresiatif. Jakarta: Salemba Humanika

Lin, L., Sidani, J. E., Shensa, A., et.al. (2016). Depression and Anxiety, 33(4) ,323-331.

Mar'at. (2009). Sikap Manusia : Perubahan serta Pengukurannya. Bandung: Ghalia Indonesia.

Marini, Sylvia. (2020). Interaksi Peer Group 
dan Intensitas Penggunaan Media Sosial Terbadap Cyberbullying Remaja. Tesis, tidak diterbitkan, Universitas Negeri Yogyakarta, Yogyakarta.

Maslim, R. (2013). Buku Saku Diagnosis Gangguan Jiwa Rujukan Ringkas dari PPDGJ-III dan DSM 5. Jakarta : Bagian Ilmu Kedokteran Jiwa FK Unika Atma Jaya

Nevid, S.J., Spencer,A.R., \& Beverly,G. (2005). Psikologi Abnormal (Edisi kelima, Jilid 1). Jakarta: Erlangga

O'Keeffe, G. S., Clarke-Pearson, K., Mulligan, D. A., et.al. (2011). Clinical report - The impact of social media on children, adolescents, and families. Pediatrics, 127(4), 800-804.

Olufadi, Y. (2016). Social networking time use scale (SONTUS): A new instrument for measuring the time spent on the social networking sites. Telematics and Informatics, 33(2), 452471.

Park, S., Inyeop K, Sang W.L., et.al. (2015). Manifestation of Depression and Loneliness on Social Networks: A Case Study of Young Adults on Facebook. Proceedings of the 18th ACM Conference on Computer Supported Cooperative Work \& Social Computing (CSCW '15). Association for Computing Machinery, New York, NY, USA, $557-570$.

Papalia, D. E., Olds, S. W., \& Feldman, R. D. (2009). Human Development Eleventh Edition. United State of America: Mc Graw Hill

Priest, R. (1987).Kecemasan dan Persepsi. Semarang: Dahara Prize

Priyanto, D. (2013). Analisis Korelasi, Regresi, dan Multivariate dengan SPSS. Yogyakarta: Gava Media.

Purwanto. (2008). Metodologi Penelitian
Kuantitatif. Yogyakarta: Pustaka Pelajar

Quadratullah, M. F. (2014). Statistika Terapan Teori, Contoh Kasus, dan Aplikasi dengan SPSS. Yogyakarta: Penerbit ANDI.

Raut, V., \& Patil, P. (2016). Use of social media in education: Positive and negative impact on the students. International Journal on Recent and Innovation Trends in Computing and Communication, 4(1), 281-285.

Rehm, L.P. (2015). Depressive Disorder: Cognitive and Behavioral Theories of Depression. USA : John Wiley \& Sons.

Richards, D., Caldwell, P.H.Y., \& Go, H. (2015). Impact of social media on the health of children and young people. Journal of Paediatrics and Child Health, 51(12), 1152-1157.

Ristekdikti. (2017). Statistik Pendidikan Tinggi Tabun 2017. Jakarta: Pusat Data dan Informasi Iptek Dikti

Rosenberg, J., \& Egbert, N. (2011). Online impression management: Personality traits and concerns for secondary goals as predictors of selfpresentation tactics on facebook. Journal of ComputerMediated Communication, 17(1), 1-18.

Rosenthal, S. R., et.al. (2016). Negative Experiences on Facebook and Depressive Symptoms Among Young Adults. Journal of Adolescent Health, 59(5), 510-516.

Sadiman, Arif S. (2003). Media Pendidikan. Jakarta: Raja Grafindo

Sahin, Cengiz. (2018). Social Media Addiction Scale-Student Form: The Reliability and Validity Study. Turkish Online Journal of Educational Technology - TOJET, 17(1), 169-182 
Salkind, Neil.J. (2010). Teori-Teori Perkembangan Manusia Sejarah Kemunculan, Konsepsi Dasar, Analisis Komparatif, dan Aplikasi (Cet.II). Bandung: Penerbit Nusa Media

Santrock, John.W. (2012). Perkembangan Masa Hidup Edisi Ketigabelas (Jilid II). Jakarta: Erlangga

Sartika, Nyimas.Y. (2019). Pengaruh Efikasi Diri, Status Sosial Ekonomi Orang Tua, Dan Intensitas Penggunaan Media Sosial Terhadap Perilaku Konsumsi Mahasiswa Di Fakultas Ekonomi Universitas Negeri Yogyakarta. Tesis, tidak diterbitkan, Universitas Negeri Yogyakarta, Yogyakarta.

Sarwono, S. W. (1978). Perbedaan Antara Pemimpin dan Aktivis dalam Gerakan Protes Mahasiswa (Cet. 1. ed.). Jakarta: Bulan Bintang

Sayekti, F., \& Putarta, P. (2016). Penerapan Technology Acceptance Model (TAM) Dalam Pengujian Model Penerimaan Sistem Informasi Keuangan Daerah. Jurnal Manajemen Teori Dan Terapan, 9(3), 196-209.

Seabrook, E.M., Kern M.L, \& Rickard N.S. (2016). Social Networking Sites, Depression, and Anxiety: A Systematic Review. JMIR Ment Health, 3(4):e50. Diambil pada tanggal 31 Mei 2020 dari https://mental.jmir.org/2016/4/e5 0/\# Results

Segal, D.L., Coolidge, F.L., Cahill, B. S., et.al. (2008). Psychometric properties of the beck depression inventory-II (BDI-II) among communitydwelling older adults. Behavior Modification, 32(1), 3-20.

Setiawati, Farida Agus. (2017). Statistika Terapan: Untuk Penelitian Pendidikan dan Sosial. Yogyakarta:Parama
Shaw, A.M., Timpano, K.R., Tran, T.B., et.al. (2015). Correlates of Facebook usage patterns: The relationship between passive Facebook use, social anxiety symptoms, and brooding. Computers in Human Behavior, 48, 575-580.

Shensa, A., Escobar-Viera, C.G., Sidani, J.E., et.al. (2017). Problematic social media use and depressive symptoms among U.S. young adults: A nationallyrepresentative study. Social Science and Medicine, 182, 150-157.

Shensa, A., Sidani, J. E., Dew, M. A., et.al. (2018). Social media use and depression and anxiety symptoms: A cluster analysis. American Journal of Health Behavior, 422, 116-128.

Singh, S., Farley, S. D., \& Donahue, J. J. (2018). Grandiosity on display: Social media behaviors and dimensions of narcissism. Personality and Individual Differences, 13(4), 308-313

Sugihartono, et.al. (2007). Psikologi Pendidikan. Yogyakarta: UNY Pers

Sugiyanto. (2004). Yogyakaria Kota Pendidikan dan Ekonomi Alternatif. Cakrawala Pendidikan, X(3), 523-547

Sugiyono. (2013). Metodelogi Penelitian Kuantitatif, Kualitatif Dan R\&D. Bandung: ALFABETA

Sulianta, Feri. (2015). Keajaiban Sosial Media. Jakarta: PT Elex Media Komputindo

Sutarsih, T., et.al. (2017). Statistik Telekomunikasi Indonesia 2017. Naskah Publikasi. Jakarta: Badan Pusat Statistika

Swartz, J.R., A.R Hariri, \& D.E. Williamson. (2016). An Epigenetic Mechanism Links Socioeconomic Status To Changes In Depression- 
Related Brain Function In High-Risk Adolescents. Molecular Psychiatry, 22(2), 209-214

Takahashi, Y., Uchida C., Miyaki K., et.al. (2009). Potential Benefits and Harms of a Peer Support Social Network Service on the Internet for People With Depressive Tendencies Qualitative Content Analysis and Social Network Analysis. J Med Internet Res, 11(3), e-29. Diambil pada tanggal 1 Juni 2020, dari https://www.jmir.org/2009/3/e29 L

Tangkudung, Joanne P. M. (2014). Proses Adaptasi Menurut Jenis Kelamin Dalam Menunjang Studi Mahasiswa FISIP Universitas Sam Ratulangi. Jurnal Acta Diurna,3(4), 1-11

Tsai, C.-W., Shen, P.-D., \& Chiang, Y.-C. (2014). Meeting ex-partners on Facebook: users' anxiety and severity of depression. Bebaviour \& Information Technology, 34(7), 668-677.

Tritt, S. M., Ryder, A. G., Ring, A. J., \& Pincus, A. L. (2010). Pathological narcissism and the depressive temperament. Journal of Affective Disorders, 122(3), 280-284.

Vannucci, A., Flannery, K.M., \& Ohannessian, C.M.C. (2017). Social media use and anxiety in emerging adults. Journal of Affective Disorders, 207, 163-166.

Vogel, E.A., Rose, J.P., Roberts, L.R., et.al. (2014). Social Comparison, Social Media, And Self-Esteem. Discover. 3(4), 206- 222.

Walsh, J. L., Fielder, R.L., Carey, K.B., et.al. (2013). Female College Students' Media Use Andacademic Outcomes Results From A Longitudinal Cohort Study. Emerging Adulthood, 1(3), 219-
232.

Wang, Y. P., \& Gorenstein, C. (2013). Psychometric Properties of The Beck Depression Inventory-II: A Comprehensive Review. Revista Brasileira de Psiquiatria, 35(4), 416431.

Wikström, Patrik \& Hanna-Kaisa Ellonen. (2012). The Impact of Social Media Features on Print Media Firms' Online Business Models. Journal of Media Business Studies, 9(3), 63-80.

Wisnubratama. (4 April 2018). Batasan Wajar Menggunakan Media Sosial Dalam Sehari. Kompas.com. Diambil pada tanggal 12 Mei 2019, dari https://lifestyle.kompas.com/read/ 2018 /04/04/053800120/ 